\title{
Optimization for Dwarf Banana with Microwave Low Temperature Carbon Dioxide Flash Puffing Process by Response Surface Methodology and Factor Analysis
}

\author{
Bao-Yu Li ${ }^{1, a}$, Kai-Dan Yin ${ }^{1}$ \\ ${ }^{1}$ Guangdong AIB Polytechnic College, Guangzhou, Guangdong, 510507, China
}

\begin{abstract}
A three factors quadratic regression rotation combination design was adopted to optimize the technical conditions of microwave low temperature carbon dioxide flash puffing (MLTCDFP) process for dwarf banana in the single factor's foundation. This paper analyzed the effect of puffing temperature, puffing pressure, vacuum drying temperature and the interaction of the three factors on color, crispness, and the effect of hardness and water content. Based on the experimental data, the quadratic regression model of four indexes was deduced, then variables were analyzed with response surface methodology (RSM). The weights of four evaluation indexes was determined by factor analysis. The regression square was obtained by the comprehensive score as follow: $Y=0.955+0.109 X_{1}+0.16 X_{3}-0.09 X_{1}^{2}+0.015 X_{2}^{2}-0.15 X_{3}^{2}-0.018 X_{1} X_{2}-0.056 X_{1} X_{3}+0.016 X_{2} X_{3}\left(\mathrm{R}^{2}=0.837\right)$. Through factor analysis, the range of the optimal technical conditions of MLTCDFP for dwarf banana obtained. The result indicated the four indexes were affected significantly by the puffing temperature and vacuum drying temperature, and the interactions of the three factors did not affect the product obviously. The optimal technical parameters were as follows: puffing temperature $91 \sim 95^{\circ} \mathrm{C}$, puffing pressure $0.11 \sim 0.19 \mathrm{MPa}$, vacuum temperature $81 \sim 85^{\circ} \mathrm{C}$.
\end{abstract}

\section{Introduction}

Dwarf banana is one of the most important tropical fruit in South of China, before lychee, pineapple, coconut [1]. Dwarf banana with rich nutrients and active ingredients, can regulate the gastrointestinal motility, beauty, enhance immunity, protecting cardiovascular, anti-cancer and other effects, highly favored by consumers [2]. Dwarf banana is a climacteric fruit species can easily degenerate during storage. Especially recently, Dwarf bananas were unmarketable, resulted in huge economic losses, seriously affected the farmers enthusiasm. It is urgent to study and develop new technology, extend the dwarf banana storage period. Researchers were studied variety drying methods, in order to prolong the shelf life of dwarf banana. Microwave low temperature carbon dioxide flash puffing (MLTCDFP) is a new non-fried puffed dehydration technology. Superheated vapour were driven by heating self-contained free water and bound water, carbon dioxide gas injected into the puffing chamber, instantaneous released at the greater than standard atmospheric pressure, produced the sponge structure. The products with excellent quality, such as maintain beauty and keep young, porous texture, saving energy, protection environmental, easy storage, convenient transportation [3-8].

In this work, deep processing of rich banana varieties, improve value-added products for the farmers' income and promote sound and rapid development of the banana industry; puffed dried banana determine the optimal process parameters, to expand the MLTCDFP technology applications to develop low-power, green nutrition processing methods, extend product shelf life.

The domestic and foreign scholars have conducted a lot of research on expanded dehydration technology. Zhu [8] were used quadratic rotation orthogonal experimental design, analysis influence factors affect the airflow puffing banana crisp process, obtained the regression equation, the optimum technological conditions were determined. Puffing temperature and puffing time on puffing degree and vitamin $\mathrm{C}(\mathrm{Vc})$ loss were significantly affected in the swelling degree increases, the volume expansion at the same time, the loss rate of $\mathrm{Vc}$ also increased. $\mathrm{Li}$ [9-12] studied banana at variable temperature and pressure difference factors of explosion puffing drying, physical property analysis on the product quality of explosion puffing drying for banana chips, the method optimizes the bananas at variable temperature and pressure difference puffing drying technology, puffing drying banana crisp aroma components were analyzed and compared by solid phase micro-extraction (SPME) coupled with gas chromatography-mass spectrometry (GC-MS). Bi [13-17] were studied the explosion puffing drying and its mechanism of fruits and vegetables, such as potato, apple, pitaya fruit, peach, the drying process parameters have been optimized. Cheng [18] were studied explosion puffing drying and isothermal adsorption characteristics of winter jujube and apple slices at

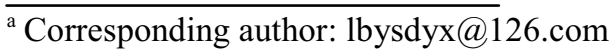


variable temperatures and pressure differences, established data model, optimization of process parameters. He [19] focused on quality properties of crispy winter jujube dried by explosion puffing drying, showed the more attractive crispness than those dried by freeze-drying and convectional hot air drying. Zou [20] were discussed effect of osmotic pretreatment on quality of mango chips by explosion puffing drying, osmotic pretreated decrease glass transition temperature, increase expansion ratio and rehydration ratio, improve hardness and crispness values than the non-pretreated samples.

The previous puffed dehydration technique study on more foreign research institutions in the Eastern United States Department of Agriculture Regional Research Center. Sullivan [21-23], who has to apples, carrots and puffed blueberry dehydration three products were studied in detail, and an important factor affecting puffing temperature, pressure, pre-drying moisture content were optimized to obtain the corresponding regression equation. Saca [24] compared with many other ordinary hot air drying of banana slices from color, moisture content, porosity, rehydration ratio and cell structure, results showed that puffed dried banana chips due to produce a more porous structure, thus has a shorter drying time and good rehydration ratio, and the rehydration process less filtered solids, the product can maintain its color, taste and texture. Banana puffing slices were manufactured by the high temperature and short time (HTST) combination with hot air dry,showed that the product quality and structure parameters (hardness, brittleness)were correlation with short -time high temperature process, but the nutrients and flavor substance loss more [25]. Chwastek [26] were discussed methods to increase the rate of mass transfer during osmotic dehydration of foods. Zotarelli [27] was to evaluate the application of a convective multi-flash drying process (CMFD) to producing dehydrated and crisp fruits. Banana processed by CMFD had a moisture content of $0.293 \mathrm{~g} / \mathrm{g}$ (dry basis) and $a w=0.272$ after $3 \mathrm{~h}$ of processing. Mango had a moisture content of $0.09 \mathrm{~g} / \mathrm{g}$ and $\mathrm{aw}=0.359$ after $4 \mathrm{~h}$ of processing. For CMFD much smaller global shrinkage was observed. Meda [28] were studied on drying kinetics and quality characteristics of microwave-vacuum dried saskatoon berries, the results shown total color difference was dependent on microwave power and vacuum pressure levels.

Dwarf banana as raw material by MLTCDFP. This paper analyzed the effect of puffing temperature, puffing pressure, vacuum drying temperature and the interaction of the three factors on color, crispness, and the effect of hardness and water content. Based on the experimental data, the quadratic regression model of four indexes was deduced, then variables were analyzed with response surface methodology (RSM). The weights of four evaluation indexes was determined by factor analysis. Aim to explore the impact of product quality, process parameters optimal level. To identify the impact of product quality dwarf banana chips significant factor, there was an interaction is significant and optimum parameters of each factor.

\section{Materials and Methods}

\subsection{Materials and instruments}

\subsubsection{Materials}

The dwarf banana fruit with the similar size and maturity were collected from Hainan province of China. The initial moisture content of the dwarf banana at $72.3 \% \pm 0.86 \%$ wet basis (w.b.).

\subsubsection{Instruments}

Texture analyzer: TMS-PRO, food technology corporation USA; Pluripotent slicer: XL-75, Guangzhou $\mathrm{Xu}$ Long Machinery Co., Ltd.; Explosion puffing equipment system: Lab-made; Vacuum microwave drying ov en: BDMDMV30, Boda microwave equipment Co., Ltd. (Henan, China); Colorimeter: NR145 Shenzhen 3nh technology CO., LTD..

\subsection{Experiment methods}

\subsubsection{Process of MLTCDFP}

Detailed process: Selected Plumpness index was greater than 8.3 (dwarf banana weight $\mathrm{g} /$ dwarf banana length $\mathrm{cm}$ ) ripe dwarf bananas as a raw material from Hainan province, water content $72.3 \% \pm 0.86 \%$, peeled, cut into uniform size $10 \mathrm{~mm}$ wafer with a slicer, then placed in a microwave oven, $60^{\circ} \mathrm{C}$ drying $30 \mathrm{~min}$. The sample was removed, placed in the puffing chamber, then puffing in different temperature, different puffing pressure, different evacuation temperature, respectively, residence $6 \mathrm{~min}$, evacuation time $70 \mathrm{~min}$. Study on the products quality were effect by the value of $\mathrm{L}^{*}$ (lightnes, white $=100$ to black $\left.=0, \mathrm{Y}_{1}\right)$, Crispness $\left(\mathrm{Y}_{2}\right)$, hardness $\left(\mathrm{Y}_{3}\right)$ and water content $\left(\mathrm{Y}_{4}\right)$.To reduce the experimental error, all operations were carried out under the same conditions in the same puffing tank, minimize interference from other factors. All the samples were stored in dryer until used.

\subsubsection{Determination of index analysis}

1) Moisture content: The moisture content of dwarf banana chips was determined by weight loss after drying $5 \mathrm{~g}$ samples in a forced air oven at $105^{\circ} \mathrm{C}$ for $24 \mathrm{~h}$ [29].

2) Texture: Texture profile analysis was used to evaluate hardness and crispness of dwarf banana chips by using a texture analyser (TMS-PRO type). The maximum compression force and the number of peaks in the force-deformation curve of each sample were considered as an indication of hardness and crispness of sample, respectively. The analysis parameters were as following: pre-test speed: $1 \mathrm{~mm} / \mathrm{s}$; test speed: $0.5 \mathrm{~mm} / \mathrm{s}$; after the test speed: $5 \mathrm{~mm} / \mathrm{s}$; test distance: $10 \mathrm{~mm}$; data acquisition rate: 200 times/s; threshold: 10g; Probe: HDP/BSK. 
3) Color: The surface color of dwarf banana chips was analyzed by a colorimeter (NR145 type). The colorimeter was calibrated against a standard white plate before each actual color measurement. The measurement of brightness index $\mathrm{L}^{*}$ of dwarf banana chips.

4) Product Quality Evaluation Method: Banana chips product lightness index $\mathrm{L}^{*}$ value is the higher the better, the Crispness values greater, hardness is low, the moisture content less than 5\% [30], the better quality of dwarf banana chips.

\subsubsection{Experimental design}

Based on the single factor experiment, selected puffing temperature $\left(\mathrm{X}_{1}\right)$, puffing pressure $\left(\mathrm{X}_{2}\right)$, vacuum temperature $\left(\mathrm{X}_{3}\right)$ three main factors as input variables, selected the product $\mathrm{L}^{*}$ value $\left(\mathrm{Y}_{1}\right)$, Crispness $\left(\mathrm{Y}_{2}\right)$, hardness $\left(\mathrm{Y}_{3}\right)$, moisture $\left(\mathrm{Y}_{4}\right)$ as output indicators, three factors quadratic regression orthogonal rotation design. The optimal level of the three factors in the single factor test was chosen as the zero level of the two regression orthogonal rotation combination design. Coding of factors and levels in Table 1.

Table 1. Coding of factors and levels

\begin{tabular}{|c|c|c|c|}
\hline $\begin{array}{c}\text { Coded } \\
\text { values }\end{array}$ & $\begin{array}{c}\mathrm{X}_{1} \text {-puffing } \\
\text { temperature } /{ }^{\circ} \mathrm{C}\end{array}$ & $\begin{array}{c}\mathrm{X}_{2} \text {-puffing } \\
\text { pressure/MPa }\end{array}$ & $\begin{array}{c}\mathrm{X}_{3} \text {-vacuum } \\
\text { temperature } /{ }^{\circ} \mathrm{C}\end{array}$ \\
\hline-1.68 & 60.0 & 0.07 & 58.0 \\
\hline-1 & 70.0 & 0.10 & 65.0 \\
\hline 0 & 85.0 & 0.15 & 75.0 \\
\hline 1 & 100.0 & 0.20 & 85.0 \\
1.68 & 110.0 & 0.33 & 92.0 \\
\hline
\end{tabular}

Table 2. Experimental designs and results

\begin{tabular}{|c|c|c|c|c|c|c|c|}
\hline No. & $\mathrm{X}_{1} /{ }^{\circ} \mathrm{C}$ & $\mathrm{X}_{2} / \mathrm{MPa}$ & $\mathrm{X}_{3} /{ }^{\circ} \mathrm{C}$ & $\mathrm{Y}_{1}-\mathrm{L}^{*}$ & $\mathrm{Y}_{2}$-Crispness/one & $\mathrm{Y}_{3}$-Hardness/N & $\mathrm{Y}_{4}$-Water content/\% \\
\hline 1 & 1 & 1 & 1 & $87.61 \pm 0.04$ & $25.22 \pm 0.05$ & $29.28 \pm 0.11$ & $3.7 \pm 0.05$ \\
\hline 2 & 1 & 1 & -1 & $86.72 \pm 0.13$ & $19.42 \pm 0.15$ & $35.32 \pm 0.15$ & $6.29 \pm 0.08$ \\
\hline 3 & 1 & -1 & 1 & $82.46 \pm 0.08$ & $21.42 \pm 0.06$ & $35.24 \pm 0.11$ & $3.56 \pm 0.12$ \\
\hline 4 & 1 & -1 & -1 & $86.27 \pm 0.11$ & $18.75 \pm 0.06$ & $29.3 \pm 0.16$ & $5.92 \pm 0.06$ \\
\hline 5 & -1 & 1 & 1 & $86.48 \pm 0.05$ & $22.62 \pm 0.04$ & $32.4 \pm 0.11$ & $3.92 \pm 0.05$ \\
\hline 6 & -1 & 1 & -1 & $79.86 \pm 0.07$ & $25.28 \pm 0.14$ & $90.29 \pm 0.09$ & $6.79 \pm 0.12$ \\
\hline 7 & -1 & -1 & 1 & $79.65 \pm 0.03$ & $16.29 \pm 0.13$ & $28.29 \pm 0.21$ & $4.78 \pm 0.10$ \\
\hline 8 & -1 & -1 & -1 & $85.43 \pm 0.02$ & $18.19 \pm 0.05$ & $115.53 \pm 0.17$ & $8.51 \pm 0.11$ \\
\hline 9 & -1.68 & 0 & 0 & $86.56 \pm 0.06$ & $0.99 \pm 0.04$ & $169.14 \pm 0.2$ & $7.98 \pm 0.05$ \\
\hline 10 & 1.68 & 0 & 0 & $87.49 \pm 0.03$ & $14.59 \pm 0.05$ & $31.73 \pm 0.17$ & $5.9 \pm 0.06$ \\
\hline 11 & 0 & -1.68 & 0 & $92.19 \pm 0.08$ & $19.44 \pm 0.48$ & $28.52 \pm 0.12$ & $5.02 \pm 0.11$ \\
\hline 12 & 0 & 1.68 & 0 & $86.17 \pm 0.04$ & $18.36 \pm 0.17$ & $35.39 \pm 0.08$ & $4.83 \pm 0.07$ \\
\hline 13 & 0 & 0 & -1.68 & $60.13 \pm 0.09$ & $0.25 \pm 0.05$ & $62.31 \pm 0.12$ & $18.2 \pm 0.10$ \\
\hline 14 & 0 & 0 & 1.68 & $81.32 \pm 0.11$ & $20.5 \pm 0.16$ & $29.33 \pm 0.17$ & $3.88 \pm 0.09$ \\
\hline 15 & 0 & 0 & 0 & $91.28 \pm 0.08$ & $29.13 \pm 0.17$ & $35.26 \pm 0.10$ & $4.7 \pm 0.15$ \\
\hline 16 & 0 & 0 & 0 & $90.63 \pm 0.07$ & $29.03 \pm 0.11$ & $34.29 \pm 0.12$ & $4.76 \pm 0.02$ \\
\hline 17 & 0 & 0 & 0 & $88.52 \pm 0.05$ & $29.64 \pm 0.10$ & $32.01 \pm 0.13$ & $4.28 \pm 0.07$ \\
\hline 18 & 0 & 0 & 0 & $90.26 \pm 0.13$ & $29.63 \pm 0.20$ & $37.77 \pm 0.11$ & $4.81 \pm 0.10$ \\
\hline 19 & 0 & 0 & 0 & $91.29 \pm 0.03$ & $29.93 \pm 0.06$ & $33.72 \pm 0.11$ & $4.8 \pm 0.08$ \\
\hline 20 & 0 & 0 & 0 & $90.26 \pm 0.02$ & $29.27 \pm 0.16$ & $43.34 \pm 0.12$ & $4.48 \pm 0.09$ \\
\hline 21 & 0 & 0 & 0 & $89.39 \pm 0.04$ & $30.18 \pm 0.07$ & $34.35 \pm 0.17$ & $4.18 \pm 0.12$ \\
\hline 22 & 0 & 0 & 0 & $90.58 \pm 0.12$ & $31.37 \pm 0.22$ & $36.28 \pm 0.12$ & $3.73 \pm 0.12$ \\
\hline 23 & 0 & 0 & 0 & $91.17 \pm 0.13$ & $29.29 \pm 0.13$ & $32.32 \pm 0.14$ & $3.59 \pm 0.09$ \\
\hline
\end{tabular}

Note: $\mathrm{X}_{1}$-puffing temperature; $\mathrm{X}_{2}$-puffing pressure; $\mathrm{X}_{3}$-evacuation temperature; $\mathrm{Y}_{1}$-lightness index $\mathrm{L}^{*} ; \mathrm{Y}_{2}$-product crispness; $\mathrm{Y}_{3}$ product hardness; $\mathrm{Y}_{4}$-product moisture content.

\subsubsection{Statistical analysis}

All experiments were performed in triplicated and the results were reported as mean values with standard deviations. All data were processed and analyzed on Data Processing System (DPS)V14.5 and STATISTICA 10.

\section{Results and Analysis}

\subsection{Test results}

According to the Process of MLTCDFP methods (2.2.1), the results were shown in Table 2 .

\subsection{Regression and parametric analysis}

The test data for regression coefficient and variance analysis(Table 3), Multiple quadratic regression equation between puffing temperature $\left(\mathrm{X}_{1}\right)$, puffing pressure $\left(\mathrm{X}_{2}\right)$, vacuum temperature $\left(\mathrm{X}_{3}\right)$ and product lightness index $\mathrm{L}^{*}$ value, crispness, hardness and moisture content as follows:

$$
\begin{aligned}
& Y_{1}=90.42+0.97 X_{1}-0.24 X_{2}+2.45 X_{3}-0.66 X_{1}^{2}-6.43 X_{3}^{2}+0.53 X \\
& { }_{1} X_{2}-0.48 X_{I} X_{3}+2.14 X_{2} X_{3} \quad\left(\mathrm{R}^{2}=0.80\right)
\end{aligned}
$$

$Y_{2}=29.42+0.27 X_{1}-0.39 X_{2}+3.55 X_{3}-6.30 X_{1}^{2}-2.43 X_{2} 2-5.38$

$X_{3}^{2}-3.84 X_{1} X_{2}+2.92 X_{1} X_{3}+1.61 X_{2} X_{3}\left(\mathrm{R}^{2}=0.76\right)$

$Y_{3}=35.69-26.98 X_{1}-0.68 X_{2}-14.71 X_{3}+20.61 X_{1}^{2}-3.62 X_{2}+1.2$

$7 X_{3}^{2}+2.63 X_{1} X_{2}+18.14 X_{1} X_{3}+2.17 X_{2} X_{3}\left(\mathrm{R}^{2}=0.89\right)$

$Y_{4}=4.39-0.59 X_{1}-0.18 X_{2}-2.61 X_{3}+0.41 X_{1}^{2}-0.30 X_{2}^{2}+1.87 X_{3}^{2}$ $+0.38 X_{1} X_{2} \quad\left(\mathrm{R}^{2}=0.88\right)$ 
Through the regression coefficient test shows that affect product $\mathrm{L}^{*}$ value, crispness and moisture content, Primary and secondary sequence are all vacuum temperature $\left(\mathrm{X}_{3}\right)>$ puffing temperature $\left(\mathrm{X}_{1}\right)>$ puffing pressure $\left(\mathrm{X}_{2}\right)$, which vacuum temperature $\left(\mathrm{X}_{3}\right)$ affected very significantly on $\mathrm{L}^{*}$ value, effect on the moisture content significantly; The primary and secondary order of factors affecting the hardness of products is puffing temperature $\left(\mathrm{X}_{1}\right)>$ vacuum temperature $\left(\mathrm{X}_{3}\right)>$ puffing pressure $\left(\mathrm{X}_{2}\right)$, which is the most significant effect on the hardness of puffing temperature $\left(\mathrm{X}_{1}\right)$ and vacuum temperature $\left(\mathrm{X}_{3}\right)$.

\subsection{Interaction analysis}

From Table 3, we can see that the interaction of puffing temperature $\left(\mathrm{X}_{1}\right)$ and puffing temperature $\left(\mathrm{X}_{3}\right)$ has a very significant effect on the hardness of products, and other interaction effects are not significant. The following is only a discussion of the impact of the interaction on the product index. In order to observe the influence of interaction, the fixed one factor is 0 level, and the interaction effect equa tion (Equation 5) and response surface diagram (Figure 1) were obtained.

$Y_{3}(1,3)=1808.46-26.63 X_{1}-13.65 X_{3}+0.093 X_{1} 2+0.1^{2} X_{1}$ $X_{3}+0.013 X_{3}^{2}$

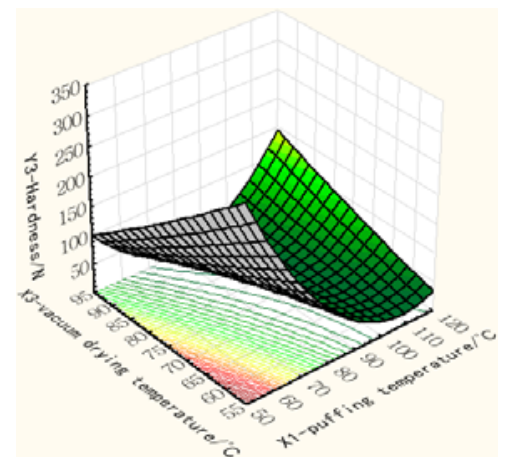

Figure 1. Effect of puffing temperature and vacuum temperature on product's hardness

Table 3. Regression coefficient and variable analysis

\begin{tabular}{|c|c|c|c|c|}
\hline index & $\mathrm{Y}_{1}$-Color & $\begin{array}{c}\mathrm{Y}_{2} \text {-Crisp- } \\
\text { ness/one }\end{array}$ & $\begin{array}{c}\mathrm{Y}_{3} \text {-Hard- } \\
\text { ness/ } \mathrm{N}\end{array}$ & $\begin{array}{c}\mathrm{Y}_{4} \text {-Water } \\
\text { content/\% }\end{array}$ \\
\hline Intercept & 90.423 & 29.424 & 35.687 & 4.399 \\
\hline $\mathrm{X}_{1}$ & 0.966 & 1.866 & $-26.958^{* *}$ & -0.591 \\
\hline $\mathrm{X}_{2}$ & -0.238 & 1.209 & -0.679 & -0.175 \\
\hline $\mathrm{X}_{3}$ & $2.448^{* *}$ & 2.784 & $-14.693^{* *}$ & $-2.609^{* *}$ \\
\hline $\mathrm{X}_{1}{ }^{*} \mathrm{X}_{1}$ & -0.731 & $-5.737^{* *}$ & $20.5044^{* *}$ & 0.411 \\
\hline $\mathrm{X}_{2}{ }^{*} \mathrm{X}_{2}$ & 0.021 & -1.886 & -3.627 & -0.302 \\
\hline $\mathrm{X}_{3}{ }^{*} \mathrm{X}_{3}$ & $-6.471^{* *}$ & $-4.8161^{* *}$ & 1.247 & $1.857^{* *}$ \\
\hline $\mathrm{X}_{1}{ }^{*} \mathrm{X}_{2}$ & 0.530 & -1.105 & 2.634 & 0.383 \\
\hline $\mathrm{X}_{1}{ }^{*} \mathrm{X}_{3}$ & -0.478 & 1.613 & $18.144^{* *}$ & 0.215 \\
\hline $\mathrm{X}_{2}{ }^{*} \mathrm{X}_{3}$ & 2.143 & 0.303 & 2.169 & 0.063 \\
\hline $\mathrm{R}^{2}$ & 0.795 & 0.761 & 0.887 & 0.879 \\
\hline
\end{tabular}

Note: $* *$ indicates significance level $\mathrm{p}<0.05, *$ represents significance level $\mathrm{p}<0.1$

\subsection{Optimization of MLTCDFP}

Through the above analysis we can see that different products have different evaluation of the regression equation, the sequence of each input variable effects on product evaluation, and the presence of significant interactions are also different, which gives the resulting optimization of process parameters some difficulties related to the process parameters of multi-objective optimization problem.

\subsubsection{Correlation between product evaluation}

Table 4. Correlation coefficient among evaluation index

\begin{tabular}{|c|c|c|c|c|}
\hline $\begin{array}{l}\text { correlation } \\
\text { coefficient }\end{array}$ & $\begin{array}{c}\mathrm{Y}_{1}-\mathrm{Co} \\
\text { lor }\end{array}$ & $\begin{array}{l}\mathrm{Y}_{2} \text {-Crisp- } \\
\text { ness/one }\end{array}$ & $\begin{array}{c}\mathrm{Y}_{3} \text {-Hard } \\
- \\
\text { ness/N }\end{array}$ & $\begin{array}{c}\mathrm{Y}_{4} \text {-Water } \\
\text { con- } \\
\text { tent } / \%\end{array}$ \\
\hline $\mathrm{Y}_{1}$-Color & 1 & & & \\
\hline $\begin{array}{l}\mathrm{Y}_{2} \text {-Crispness } \\
\text { /one }\end{array}$ & $0.67^{* *}$ & 1 & & \\
\hline $\begin{array}{c}\mathrm{Y}_{3} \text {-Hardness } \\
/ \mathrm{N}\end{array}$ & -0.2 & $-0.54^{* *}$ & 1 & \\
\hline $\begin{array}{l}\mathrm{Y}_{4} \text {-Water } \\
\text { content } / \%\end{array}$ & $-0.81^{*}$ & $-0.72^{* *}$ & $0.44^{*}$ & 1 \\
\hline
\end{tabular}

NOTE: correlation coefficient threshold value, when $\mathrm{a}=0.05$, $\mathrm{r}=0.4132$; when $\mathrm{a}=0.01, \mathrm{r}=0.5256$.

As can be seen from Table 4, there is a correlation between the product evaluation, product lightness index $\mathrm{L}^{*}$ value and crispness significant positive correlation, and the moisture content was significantly negatively correlated. Product friability and hardness significantly negatively correlated with the moisture content was significantly negatively correlated. Product hardness and moisture content was significantly negatively correlated. That product lightness index $\mathrm{L}^{*}$ value, the higher the product crispness, the lower the moisture content; the higher the crispness of the product, lower product hardness, the lower the moisture content. Products of high hardness, which mean high moisture content of the product.

\subsubsection{Factor Analysis (FA)}

FA is from the internal study variables related dependencies starting some variables with complex relationships attributed to a few factors in a comprehensive multivariate statistical analysis. Its basic idea is to classify the observed variables, the correlation is high, that is more closely linked in the same sub-class, but not the same correlation between variables is low, then the variable is actually representative of each category a basic structure, that common factors. For the problem under study is a linear function of trying to use the minimum number of unpredictable factors in the so-called public and special factors and to describe each component of the original observations.

According to the principle of FA to construct puffed products target parameter factor loading matrix, calculating the correlation coefficient matrix of eigenvalues, characteristic features of the cumulative contribution rate and the contribution rate, the results shown in Table 5. 
Table 5. Eigenvalues and Cumulative contribution rate of correlated matrix

\begin{tabular}{|c|c|c|c|}
\hline No. & Eigenvalues & $\begin{array}{c}\text { Contribution } \\
\text { rate/\% }\end{array}$ & $\begin{array}{c}\text { Cumulative contri- } \\
\text { bution rate/\% }\end{array}$ \\
\hline 1 & 3.4408 & 86.0191 & 86.0191 \\
\hline 2 & 0.4325 & 10.8135 & 96.8326 \\
\hline 3 & 0.0884 & 2.2099 & 99.0425 \\
\hline 4 & 0.0383 & 0.9575 & 100 \\
\hline
\end{tabular}

According eigenvalues shows the cumulative contribution rate, when taken three common factors, the cumulative variance contribution rate has reached $99.0425 \%$. Take three common factors to build a matrix of factor loadings and variance orthogonal rotation method was a great factor loading matrix (Table 6).

By Table 6 shows that the common factor $\mathrm{fl}$ product lightness index $\mathrm{L}^{*}$, moisture dominant role of these indicators is the color of the main reaction product, it can be referred to as the color factor $\mathrm{fl}$; $\mathrm{f} 2$ common factor plays a dominant role on the hardness of the product, So can be said for the hardness factor $\mathrm{f} 2$; $\mathrm{f} 3$ common factor from the crispness of the dominant role of the product, it can be named as crispness factor $\mathrm{f}$.

Table 6. Rotated factor loading matrix

\begin{tabular}{|c|c|c|c|}
\hline rotated factor matrix & $\begin{array}{c}\text { Factor } \\
\text { No. f1 }\end{array}$ & $\begin{array}{c}\text { Factor } \\
\text { No. f2 }\end{array}$ & $\begin{array}{c}\text { Factor } \\
\text { No. f3 }\end{array}$ \\
\hline Color/ L $^{*}$ & 0.9070 & 0.0065 & 0.3295 \\
\hline Crispness/one & 0.4562 & -0.3220 & 0.8280 \\
\hline Hardness/N & -0.1245 & 0.9640 & -0.2119 \\
\hline Water content/\% & -0.8790 & 0.3100 & -0.2540 \\
\hline Variance contribution & 1.8190 & 1.1290 & 0.9037 \\
\hline $\begin{array}{c}\text { Cumulative contribu- } \\
\text { tion }\end{array}$ & 0.4547 & 0.7370 & 0.9629 \\
\hline \begin{tabular}{c} 
Weight coefficient \\
\hline
\end{tabular} & 0.45 & 0.29 & 0.22 \\
\hline
\end{tabular}

Table 7 Compoment Score Coefficient Matrix and comprehensive evaluation value of samples

\begin{tabular}{|c|c|c|c|c|c|c|c|c|}
\hline No. & $\begin{array}{c}\text { Puffing temper- } \\
\text { ature }\left(\mathrm{X}_{1}\right)\end{array}$ & $\begin{array}{c}\text { Puffing } \\
\text { pressure }\left(\mathrm{X}_{2}\right)\end{array}$ & $\begin{array}{c}\text { Vacuum tem- } \\
\text { perature }\left(\mathrm{X}_{3}\right)\end{array}$ & $\mathrm{Y}(\mathrm{i}, 1)$ & $\mathrm{Y}(\mathrm{i}, 2)$ & $\mathrm{Y}(\mathrm{i}, 3)$ & $\begin{array}{c}\text { Comprehensive } \\
\text { evaluation value }\end{array}$ & $\begin{array}{c}\text { Standard- } \\
\text { ization }\end{array}$ \\
\hline $\mathrm{N}(1)$ & 1 & 1 & 1 & 0.3936 & -0.5426 & -0.0081 & 0.348889 & 0.9544 \\
\hline $\mathrm{N}(2)$ & 1 & 1 & -1 & 0.0001 & -0.3558 & -0.4544 & 0.009321 & 0.8213 \\
\hline $\mathrm{N}(3)$ & 1 & -1 & 1 & 0.1274 & -0.6546 & -0.5403 & 0.14261 & 0.8735 \\
\hline $\mathrm{N}(4)$ & 1 & -1 & -1 & 0.0835 & -0.6108 & -0.7217 & 0.067063 & 0.8439 \\
\hline $\mathrm{N}(5)$ & -1 & 1 & 1 & 0.3765 & -0.5406 & -0.3771 & 0.255684 & 0.9179 \\
\hline $\mathrm{N}(6)$ & -1 & 1 & -1 & -0.9889 & 1.3314 & 1.3905 & -0.551215 & 0.6014 \\
\hline $\mathrm{N}(7)$ & -1 & -1 & 1 & -0.1675 & -1.0357 & -1.2530 & -0.032141 & 0.8050 \\
\hline $\mathrm{N}(8)$ & -1 & -1 & -1 & -0.4159 & 2.2441 & 0.5556 & -0.777456 & 0.5127 \\
\hline $\mathrm{N}(9)$ & -1.68 & 0 & 0 & 0.8935 & 3.4286 & -2.2125 & -1.203907 & 0.3454 \\
\hline $\mathrm{N}(10)$ & 1.68 & 0 & 0 & 0.4335 & -0.6132 & -1.4840 & 0.049979 & 0.8372 \\
\hline $\mathrm{N}(11)$ & 0 & -1.68 & 0 & 0.8538 & -0.4817 & -0.9710 & 0.315024 & 0.9412 \\
\hline $\mathrm{N}(12)$ & 0 & 1.68 & 0 & 0.3634 & -0.5162 & -0.9541 & 0.109271 & 0.8605 \\
\hline $\mathrm{N}(13)$ & 0 & 0 & -1.68 & -4.3443 & -0.1361 & -0.7532 & -2.084619 & 0.0000 \\
\hline $\mathrm{N}(14)$ & 0 & 0 & 1.68 & -0.0185 & -0.8857 & -0.6647 & 0.12225 & 0.8655 \\
\hline $\mathrm{N}(15)$ & 0 & 0 & 0 & 0.3181 & -0.0394 & 0.8620 & 0.354035 & 0.9565 \\
\hline $\mathrm{N}(16)$ & 0 & 0 & 0 & 0.2228 & -0.0847 & 0.8841 & 0.330761 & 0.9473 \\
\hline $\mathrm{N}(17)$ & 0 & 0 & 0 & 0.1057 & -0.2512 & 0.9218 & 0.339995 & 0.9509 \\
\hline $\mathrm{N}(18)$ & 0 & 0 & 0 & 0.1635 & 0.0257 & 1.0263 & 0.3014 & 0.9358 \\
\hline $\mathrm{N}(19)$ & 0 & 0 & 0 & 0.2340 & -0.0512 & 1.0333 & 0.359343 & 0.9585 \\
\hline $\mathrm{N}(20)$ & 0 & 0 & 0 & 0.2708 & 0.1672 & 0.9568 & 0.288452 & 0.9307 \\
\hline $\mathrm{N}(21)$ & 0 & 0 & 0 & 0.1878 & -0.1442 & 1.0028 & 0.361298 & 0.9593 \\
\hline $\mathrm{N}(22)$ & 0 & 0 & 0 & 0.3602 & -0.0405 & 1.1041 & 0.428993 & 0.9859 \\
\hline $\mathrm{N}(23)$ & 0 & 0 & 0 & 0.5466 & -0.2126 & 0.6568 & 0.465066 & 1.0000 \\
\hline
\end{tabular}

Evaluation puffed food evaluation index should give priority to product color. Secondly, we should consider crisp property. Finally, considering the moisture content of the product, also hope to get the product color lightness index as much as possible higher and crispness as far as possible big, hardness as far as possible small, in view of the above analysis and factor loading matrix of the cumulative contribution rate, were given the common factor F1, common factor F2 and common factor F3, 0.45, $0.29,0.22$ heavy, and the common factor $\mathrm{f} 2$ gives negative weight.

After varimax orthogonal rotation sample obtained scores, the scores of each sample above right conferred by a weighted sum of the weight of each sample to obtain a comprehensive score in Table 7.

\subsubsection{Regression analysis}

Application of response surface methodology (RSM) to composite score as the target parameter to obtain the operating parameters of the product composite score of response surface (Figure 2) and $\alpha=0.10$ significance level regression equation as follows:

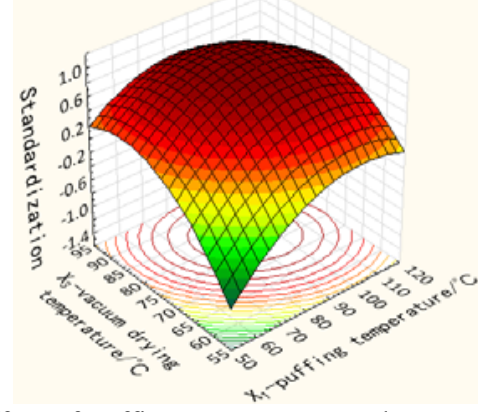

Figure 2. Effect of puffing temperature and vacuum temperature on product's comprehensive evaluation value 


$$
\begin{aligned}
& Y=0.955+0.109 X_{1}+0.16 X_{3}-0.09 X_{1}^{2}+0.015 X_{2}^{2}-0.15 X_{3}^{2}-0.0 \\
& 18 X_{1} X_{2}-0.056 X_{1} X_{3}+0.016 X_{2} X_{3} \quad\left(R^{2}=0.837\right)
\end{aligned}
$$

As can be seen from the regression equation 6, puffing temperature $\left(\mathrm{X}_{1}\right)$ and vacuum temperature $\left(\mathrm{X}_{3}\right)$ is the most important factor affecting the product's comprehensive score, and can be seen in its first term are all positive effects, which are all quadratic term negative effects, this shows puffing temperature $\left(\mathrm{X}_{1}\right)$ and vacuum temperature $\left(\mathrm{X}_{3}\right)$ on the product value comprehensive score due to their different level.

\subsubsection{Optimization of process parameters based on comprehensive scoring}

Combined with sensory evaluation, when the composite score $\geqslant 0.80$, the product combines quality (texture, color, taste, etc.) is more desirable. Therefore, taking the composite score $\geqslant 0.80$. According to the regression equation, the application of frequency analysis, computer simulation, to find the optimal combination of program operation parameters. The results showed (Table 8), a total of 40 programs to meet the requirements. From the last row of the table, while puffing temperature is $91 \sim$ $95^{\circ} \mathrm{C}$, puffing pressure is $0.11 \sim 0.19 \mathrm{MPa}$, evacuated temperature $81 \sim 85^{\circ} \mathrm{C}$, the composite score is higher than $95 \%$ probability 0.80 .

\subsubsection{Verification test}

The test verified under this condition banana chips produced by the Comprehensive score is greater than 0.80 , product quality excellent to satisfactory results (Figure 3). Through the optimization of comprehensive evaluation, to multi-objective optimization purposes.

\section{Conclusions}

Three-factor quadratic regression orthogonal rotation design, the establishment of four indicators quadratic polynomial model by DPSV14.5 and STATISTICA 10.0

\begin{tabular}{|c|c|c|c|c|c|c|c|}
\hline \multirow{2}{*}{\multicolumn{2}{|c|}{ Factor }} & \multicolumn{2}{|c|}{ Puffing temperature } & \multicolumn{2}{|c|}{ Puffing pressure } & \multicolumn{2}{|c|}{ Vacuum temperature } \\
\hline & & $\mathrm{X}_{1}$ & Frequence & $\mathrm{X}_{2}$ & Frequence & $\mathrm{X}_{3}$ & Frequence \\
\hline \multirow{5}{*}{ Level } & -1.6818 & 0 & 0.0000 & 8 & 0.2000 & 0 & 0.0000 \\
\hline & -1 & 0 & 0.0000 & 8 & 0.2000 & 0 & 0.0000 \\
\hline & 0 & 15 & 0.3750 & 8 & 0.2000 & 15 & 0.3750 \\
\hline & 1 & 15 & 0.3750 & 8 & 0.2000 & 15 & 0.3750 \\
\hline & 1.6818 & 10 & 0.2500 & 8 & 0.2000 & 10 & 0.2500 \\
\hline \multicolumn{2}{|c|}{ Weighted average } & \multicolumn{2}{|c|}{0.7950} & \multicolumn{2}{|c|}{0} & \multicolumn{2}{|c|}{0.7950} \\
\hline \multicolumn{2}{|c|}{ Standard error } & \multicolumn{2}{|c|}{0.1060} & \multicolumn{2}{|c|}{0.196} & \multicolumn{2}{|c|}{0.106} \\
\hline \multicolumn{2}{|c|}{$95 \%$ Confidence interval } & \multicolumn{2}{|c|}{$0.588 \sim 1.003$} & \multicolumn{2}{|c|}{$-0.38 \sim 0.384$} & \multicolumn{2}{|c|}{$0.588 \sim 1.003$} \\
\hline \multicolumn{2}{|c|}{ Parameter range } & \multicolumn{2}{|c|}{$91 \sim 95^{\circ} \mathrm{C}$} & \multicolumn{2}{|c|}{$0.11 \sim 0.19 \mathrm{MPa}$} & \multicolumn{2}{|c|}{$81 \sim 85^{\circ} \mathrm{C}$} \\
\hline
\end{tabular}

Table 8. Optimized result based on frequency analysis

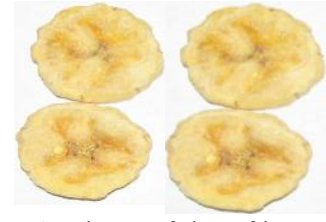

Figure 3. Photo of dwarf banana chips software.

According to the relationship between the various indicators by FA, statistical weight were given by contribution of the product quality,ultimately get the composite score and establish regression equation.

$$
\begin{gathered}
Y=0.955+0.109 X_{1}+0.16 X_{3}-0.09 X_{1}^{2}+0.015 X_{2}^{2}-0.15 X \\
3_{3}^{2}-0.018 X_{1} X_{2}-0.056 X_{1} X_{3}+0.016 X_{2} X_{3} \quad\left(R^{2}=0.837\right) .
\end{gathered}
$$

Comprehensive evaluation of the results of the experiment showed that the puffing temperature and vacuum temperature, which were affected significantly on the $L^{*}$ value, hardness and water content. No significant interaction between puffing temperature, puffing pressure and vacuum temperature.

MLTCDFP dehydrated dwarf banana optimum parameters were: puffing temperature $91 \sim 95{ }^{\circ} \mathrm{C}$, puffing pressure $0.11 \sim 0.19 \mathrm{MPa}$, vacuum temperature $81 \sim 85^{\circ} \mathrm{C}$.

\section{References}

1. Y. A. Zhou, Health functions of bananas, Food and Nutrition in China, 3: 51-52 (2006).

2. J.Cai, Talking about the health care function of banana, Food and Drugs, 7 (3A): 65-67 (2005).

3. C.M.Zmamer, Gun-puffed vegetable snacks: A new way to eat your veggies, Food Technol., 49(10): 64-65(1995).

4. J. F. Sullivan, J. C. Craig, The development of explosion puffing, Food Technol., 38(2): 52-55 (1984).

5. J. F. Sullivan, M.J. Egoville, R.P. Konstance, Storage stability of continuous explosion puffed potatoes,Food Sci.Technol., 16(2):76(1983).

6. A. I. Varnalis,J. G. Brennan, D.B.MacDougall, A proposed mechanism of high-temperature puffing of puffing. Part I .The influence of blanching and drying condition on the volume of puffed cubes , J.F.E., 48:361-367(2001).

7. J. f. Bi, Y. M. Wei,Fruit and vegetable variable temperature differential puffing drying technology research progress, Transactions of the Chin. Soci. of Agric. Eng., 24 (6): 308-312(2008). 
8. L.L.Zhu, P. Z. Zhang, K.Li, Non fried puffing banana chips technology research, Food. R.\&D., 26 (2): 75-77(2006).

9. B.Y.Li, J.f.Bi,F. Fang, Research of the Impact Factors Explosion Puffing Drying by Modified Temperature and Pressure for Banana chips,Food R.\&D., 31(5):29-32(2010).

10. B.Y.Li, Physical Property Analysis on the Product Quality of Explosion Puffing Drying for Banana Chips, Farm Products Processing, 387(7): 8-10 (2015).

11. B.Y.Li, J.Yang, K.D.Yin, Analysis of Aroma Components of Banana Slices before and after Explosion Puffing Drying at Modified Temperature and Pressure by SPME- GC-MS, Food Sci., 35(1):184-188 (2014).

12. B.Y.Li, J.Yang, K.D.Yin, An Analysis of Flavour Compounds of Bananas under Different Drying Methods on the Basis of GC-MS Computer Technology,A.M.M., ICMTTME6,5136-5340(2014).

13. J.f.Bi, The response surface method optimization potato variable temperature differential puffing drying technology research, Food Sci., 28 (11): 236 -240 (2007).

14. J.f.Bi, Y.M.Wei, D.Wang, Cantaloupe variable temperature differential pressure extruding technology optimization study, J. Agric. Eng., 24 (3): 232 -237 (2008).

15. J.f.Bi, A.J.Y, X.Liu, Effects of pretreatments on explosion puffing drying kinetics of apple chips, LWT-food sci. technol., 60(2):1136-1142(2015).

16. J.Y. Yi, L.Y. Zhou, J.f.Bi, Influences of microwave pre-drying and explosion puffing drying induced cell wall polysaccharide modification on physicochemical properties, texture, microstructure and rehydration of pitaya fruit chips, LWT-food sci. technol.,70:271-279(2016).

17. J.L.Yu, L.Y. Zhou, J.f.Bi,X.Liu, X.Y.Wu. Quality evaluation of yellow peach chips prepared by explosion puffing drying, J. Food Sci. Technol., 52(12): 8204-8211(2015).

18. L.L.Cheng.Explosion Puffing Drying and Isothermal Adsorption Characteristics of Winter Jujube and Apple Slices at variable temperatures and Pressure differences, Hefei,: Anhui Agric. Univ.,(2012).

19. X.Y.He, J.F. Liu, L.L.Cheng, Quality Properties of Crispy Winter jujube Dried by Explosion Puffing Drying, INT. J. Food Eng., 9(1):99 - 106(2013).

20. K.Zou, J.Teng, L.Huang, X.Dai, \& B.Wei, Effect of osmotic pretreatment on quality of mango chips by explosion puffing drying. LWT-food sci. technol., 51(1), 253- 259 (2013).

21. J.F.Sullivan, J.C.Craig, J. R, R.P.Konstance, Egoville M J. Continous Explosion-Puffing of apples ,J. Food Sci., 46: 1550-1555(1980).

22. J.F.Sullivan, R.P.Konstance, E.S,Dellamonica,Carrot dehydration-optimization process studies on the explosion-puffing process ,J. Food. Sci., 46:1537-1542 (1981).

23. J.F.Sullivan, J.C. Craig, E.D.Dekazos, S.M. Leiby, R.P. Konstanc, Dehydrated blueberries by the continuous explosion-puffing process, Food Sci., 1982, 47(2): 445-448.

24. S.A.Saca, J. E. Lozano, Explosion puffing of bananas, INT. J .Food Sci. Technol., 27: 419-426(1992).

25. K.Hofsetz, C.C.Lopes. Crispy banana obtained by the combination of HTST and a drying process, 14th IDS: 1699-1706 (2004).

26. A. Chwastek. Methods to increase the rate of mass transfer during osmotic dehydration of foods, Acta Sci. Pol., Technol. Aliment. 13(4):341-350(2014).

27. M. F. Zotarelli, B.D.A. Porciuncula, J.B.Laurindo. A convective multi-flash drying process for producing dehydrated crispy fruits. J. Food Eng., 108: 523-531 (2012).

28. V.Meda,M.Gupta,A.Opoku,drying kinetics and quality characteristics of microwave-vacuum dried saskatoon berries, J. Microwave Power \& Electromagnetic Energy ONLINE, 42, 4(2008).

29. AOAC (1986) Method 986.21 Moisture in spices distillation methods.USA: offcial methods of analysis of AOAC international.

30. National health and family planning committee of the PRC, the national food safety standards puffed food GB 17401-2014, Beijing, (2014). 